\title{
KTO JEST AUTOREM PIERWSZYCH POLSKICH ARTYKUŁÓW PATRYSTYCZNYCH?
}

Kiedy w 1873 r. Filoteusz Bryennios, profesor wyższej szkoły patriarchalnej w Konstantynopolu, a od 1877 metropolita Nikomedii, odkrył w bibliotece monasteru patriarchalnego werozolimie kodeks z r. 1056 zawierajłcy m.in. "Naukę dwunastu apostołów", cytowaną od pierwszego słowa greckiego jako "Didache" oraz opublikował ja w 1883 r., zdano sobie od razu sprawę z doniosłości tego odkrycia. Jak z rogu obfitości posypały się studia, komentarze i nowe wydania tekstu. Niedawno minęło 100 lat od tej publikacji, której bibliografia rośnie bez przerwy wręcz lawinowo, a mimo ogromnych wysiłków nie zdołano jeszcze wszystkiego ostatecznie ustalić, ot choćby sprawe 9110 rozdziału /modlitwy eucharystyczne czy modlitwy przy posiłku/.

Na chwałę naszych przodków z XIX w. trzeba powiedzieć, że z poinformowaniem społeczeństwa o tym doniosłym znalezisku nie czekali całymi latami, co dzisiaj stało się niemal regulą, ale chwyci$11 \mathrm{za}$ pióro natychmiast. Oto już grudniowy zeszyt "Przeglądu Polskiego" z 1884 r. zamieścił doskonale informujący artykuł pt. "Nowo odkryty tekst grecki "Nauki Apostołów"1, a w następnym $1885 \mathrm{r}$. jezuicki "Przegląd Powszechny" ogłosił pierwszy/do dziś jest'ich pięćf polski przekład "Didache" dokonany przez ks. Władysława Chotkowskiego ${ }^{2}$.

Kto jest autorem tego pierwszego artykułu o "Didache"w "Przeglądzie Polskim"? "Słownik polskich teologów katolickich" pod redakcją ks. Hieronima Eugeniusza Wyczawskiego proponuje nam dwóch autorów. Zmartwychwstaniec ks. Bolesław Micewski przypisuje go swe-

1 "Przegląd Polski" 19/1884/ t. 74, 530-534.

2 Nowo znaleziona "Nauka dwunastu Apostołów", "Przegląd Powszechny" $2 / 1885 / t .5,232-249,371-384$. 
mu konfratrowi ks. Stefanowi Pawlickiemu ${ }^{3}$, natomiast ks. Bolesław Kumor uznał go za własność ks. Stanisława Puszeta ${ }^{4}$. Któż więc jest autorem, Pawlicki czy Puszet? - Oto jest pytanie pierwsze.

Drugim nie rozstrzygniętym dotąd problemem jest pytanie, kto jest autorem 15-odcinkowego cyklu artykułów pt. "0jcowie święci

1 pisarze Kościoła", opublikowanego w $1863 \mathrm{r}$. na łamach warszawskiego tygodnika "Przegląd Katolicki" 5 . Było to na naszym terenie pierwsze tego rodzaju opracowanie całej patrystyk1. Rozmiłowany w Ojcach Kościoła autor gorzko ubolewał na wstępie, że ojcowie są u nas nieznani, a co gorsza, sa nawet - jak powiada, "w poniewierce" /s. 433/. ojcowie Kościoła dla ludzi zarażonych racjonalizmem 1 duchem oświecenia "to arcynudni kaznodzieje 1 moraliści dawnych ciemnych wieków. Do lch dzieł nie ma po co zaglądać"/s. 433/. Do tych racjonalistycznych uprzedzeń dołącza się pospolita ignorancja. Trudno przecieź polubić to, czego się nie zna. Bardzo nad tym ubolewał autor i postanowił temu zaradzić. Plan wytknął sobie następujący: "Tej ujmy, jaka się dzieje świętej powadze 0jców, z naszej strony inaczej usunąć nie moz̉emy, jak tylko obznajmianiem z nimi publiczności, za czym pójdzie przekonanie, że 0jcowle święci są rzeczywiście kwiatem ludzkości $i$ że pisarze Kościoła stoją na przedzie między najznakomitszymi w świecie umysłowym mężami. W tym celu zamierzamy w kilku artykułach podać ogólny rys pracy i zasług 0jców świętych 1 pisarzy Kościoła, a następnie zapoznać czytelników bliżej z najznakomitszymi pomiędzy nimi postaciami"/s. 433/. Takie były założenia autora.

3 Por. Pawlicki Stefan Zachariasz/1839-1916/, w: Słownik polskich teologów katolickich III, Warszawa 1982, 317, nr 37 .

4 Por. Puszet Stanisław/1841-1907/, tamże, 461, nr 6.

5 "Przegląd Katolicki" 1/1863/433-437: Apologec1, 450-455, 470-476: Szkoła Aleksandryjska, 485-493: Złoty wiek literatury duchownej, 500-507: Wieki upadku literatury duchownej, 516-523: Wojny Krzyżowe, 530-535: Naukowe wykształcenie 0jców Swiętych/Filozopia/, 563-569/Poezja/, 595-600/Wymowa/, 612-615, 629-636, 644-653, 659-666 /Historia/, 676-679: Ukształcenie 0jców św. W innych naukach i sztukach pięknych. Zakończenie. 
Zrealizował je dając szkic całej patrystyki w siedmiu rozdziałach. W. pierwszym omówił apologetów/0jców apostolskich całkiem pominął/, przedstawił genezę 1 tło historyczne apologetyki, ale, rzecz zadziwiająca, jako jej przykład podał niemal pełny przekład Hermiasza "Szydzenie z filozofów pogańskich"/s. 435-437/. Trudno doprawdy o llustracje bardziej chybioną, bo ten satyryczny i zgryźliwy paszkwil płytkiego umysłu do tego celu najmniej się nadawał. Z autorów łacińskfch omówił Tertuliana przytaczając pierwszy rozdział "Apologetyku", gdzie ten gorący adwokat afrykański zarzuca przedstawicielom władz rzymskich całkowitą ignorancję chrześcijaństwa, a waśnie ona jest przyczyną nienawiści $i$ prześladowania chrześcijan /s. 451-452/. Dorzucił jeszcze kilka innych fragmentów "Apologetyku" i księgi "O przedawnieniu". W rozdziale drugim pt. "Szkoła aleksandryjska" omówił Klemensa $i$ Orygenesa przytaczając wypisy z "Upomnienia" 1 z "Contra Celsum". Rozdział trzeci pt. "Złoty wiek literatury duchownej" podał ogólną charakterystykę epoki i głównych ośrodków, w których rozwijało się chrześcijaństwo i jego literatura/Antiochia, Konstantynopol, Rzym/. Natomiast przedstawienie poszczegó1nych 0jców przesunął do dalszych rozdziałów, konkretnie do szóstego. Rozdział czwarty zatytułował autor ostro $\mathbf{i}$ chyba krzywdząco jako "Wieki upadku literatury duchownej", a jako ich reprezentantów uznał Salwiana $i$ Wincentego z Lerynu, co musi budzić zdziwienie tym bardziej, że przytoczone z obu urywki wcale tego nie dowodza. Rozdziaz piąty poświęcił "Wojnom Krzyżowym" chyba tylko po to, żeby przedstawić św. Bernarda, którego wówczas niektórzy włączali do patrystyki. Następuje teraz rozdział najobszerniejszy, zawierający materiał maściwej patrystyki niezgrabnie zatytułowany "Naukowe wykształcenie 0jców świętych". Obejmuje on w "Przeglądzie" odcinki od 7 do 14. Omówił w nim autor konkretnych 0jców, grupując ich wokół sześciu haseł wywoławczych: filozofia, filologia, poezja, wymowa/ten podrozdzial wypadł najobszerniej/, historia i wykształcenie ojców w innych naukach i sztukach pięknych. Całość opracowania zamyka rozdział siódmy "Zakończenie".

Co sądzić o tej pracy? Kryteriów dzisiejszych przykładać do niej nie można. Na tle tamtych czasów, w warunkach niewoli była ona niewątpliwym osiągnięciem, mimo swej nierównośc1, mimo tonu apologetycznego, mimo wyraźnego niedoceniania literatur antycznych. Napisał autor $i$ takie oto zdanie: "Czas domierzył im /= autorom po- 
gańskim/ sprawiedliwość, zaschła $i$ obumarła wraz z pogaństwem literatura pogańska $i$ wsiażkach jeno pozostała, jako zasuszony kwiat bez woni i życia przechowuje się w zielniku"/s. 549/. Być może ówczesne warunki w zaborze rosyjskim uprawniały go do tak zadziwiajacych sformułowań, ale dziś, kiedy wysokie nawet nakłady Herodota, Tucydydesa, Tacyta, Horacego 1 wielu, wielu innych autorów antycznych rozchodzą się błyskawicznie, o zielniku mówié nie podobna. Szkoda przy tym wszystkim, że praca ta nie ukazała się w formie ksiązkowej 1 całkowicie utonęła w foliałach tygodnika, skutkiem czego nie jest nigdzie cytowana.

Pod ostatnim odcinkiem omawianej pracy widnieje podpis w formie: Ks.J.S. Kto się kryje za tymi literkami? Udajemy się znów do "Słownika polskich teologów katolickich", gdzie ks. Michał Grzybowski umieszcza go w bibllografii Juliana Smoleńskiego, proboszcza w Joń$\mathrm{cu}^{6}$, a Ryszard Żmuda przypisuje go ks. Józefowi Szpaderskiemu, proPesorowi patrologii Warszawie ${ }^{7}$. Któż więc Paktycznie jest autorem tej wieloodcinkowej rozprawy?

Warto na zakończenie przypomnieć, że w 1863 r., w którym wydrukowano omawianą rozprawe, obchodzono uroczyście "tysiącletnią rocznicę zaprowadzenia chrześcijaństwa w naszym kraju". Czczono przybycie braci sołuńskich Cyryla i Metodego na Morawy. Jak wówczas Seminaria Duchowne uczciły tę rocznicę? Poznań sprowadził całego Migne'a, który liczy ogółem 1071 tomów $^{8}$, bo prócz patrologii wydał on wielotomową bibliotekę egzegetyczną, kaznodziejską itp. Podobnie

6 Por. Smoleński Julian /1834-1909/, w: Słownik polskich teologóm katolickich. IV, Warszawa 1983, 116, nr 5 .

7 Por. Szpaderski Józep /1816-1877/, tamże, 282, nr 12.

8 Kronika kościelna krajowa, "Przegląd Katolicki" 1/1863/220/nr 14 9 kwietnia/: "Niektórzy z duchownych Archidiecezji Gnieźnieńskiej I Poznańskiej powzięli chwalebną myśl uświęcić pamiątkę tysiącletniej rocznicy zaprowadzenia chrześcijaństwa w naszym kraju, którą w roku bieżacym obchodzimy, nabyciem przez duchowieństwo obu archi diecezji na rzecz biblioteki arcybiskupiego seminarium w Poznaniu kosztownego zbioru dzieł kościelnych, które ks. Migne w Paryźu wydaje. Nabycie zbioru tego ma by é w ten sposób ułatwione, ze każdy z duchownych zobowiąże się liczbę mszy św. na niego przypadająca odprawić ... ... Za zbiór bowiem już wydrukowanych 1 drukujących się dzieł, które wynoszż 1071 tomów /a między temi są pisma wszystkich $0 j$ ców łacińskich $i$ greckich/ks. Migne ząda odprawienia mszy św. 6323 . 
postąpił Przemyśl, o czym pisał kronikarz przemyski "Da Bóg zdrowia, niepłonną mamy nadzieję, że nie tylko na pojedynczych plebaniach spotkasz się z dziełami ojców teologów i kanonistów, ale powoli zaczną się formować biblioteki dekanalne" ${ }^{9}$. Minęło dokładnie 120 lat 1 spróbujmy sobie wyobrazić dzisiejszą plebanię z grecką 1 racińską Patrologią Migne'a!

\section{Andrzej Bober SJ.}

\section{DE AUCTORIBUS QUAERENDIS \\ DUARUM POLONORUM DISSERTATIONUM PATRISTICARUM /Argumentum/}

Hac in brevi dissertiuncula inquiruntur veri auctores duarum Polonorum dissertationum patristicarum, quae saeculo exeunte conscriptae sunt. Auctor prioris, quae in "Przegląd Polski" anno 1884 publicata de "Didachen tractat, solummodo initialibus S.P. subscribitur. Auctor autem alterius, quae sub titulo "Patres sancti et scriptores Ecclesiae" XV partiunculis in "Przegląd Polski" anno 1863 publicata est, pariter solis litteris Ks. J.S. subnotatur.

9 Tamże, $235 / \mathrm{nr} 15,16 \mathrm{kwietnia/:} \mathrm{"Dzisiaj/10} \mathrm{marca/} \mathrm{przyszedł}$ nowy transport książek z Paryza wydawnictwa ks. Migne a, zawierający tomów $1105 \mathrm{za} 6515 \mathrm{oblig}$ mszalnych. Z tej sumy, tomów 200 przypada dla biblioteki seminaryjnej, a reszta idzie na diecezje naszą lwowską. Czwarta to z kolei przesyłka, która z poprzednimi zliczona czyni 3661 tomów za 22065 oblig mszalnych ...". 